\title{
Optimization of hydrolyzation procedure for amino acid analysis in fish meat with HPLC-DAD by Response Surface Methodology (RSM)
}

\section{Balık etinde HPLC-DAD ile yapılan amino asit analizi hidrolizasyon prosedürünün Yanıt Yüzey Metodu (RSM) ile optimizasyonu}

\author{
Ekrem Cem Çankırılıgil ${ }^{1}$ - Nermin Berik ${ }^{2^{*}}$ • Esen Alp Erbay ${ }^{3}$ \\ ${ }^{1}$ Central Fisheries Research Institute, Department of Aquaculture, 61100, Trabzon, Turkey \\ https://orcid.org/0000-0001-5898-4469 \\ ${ }^{2}$ Faculty of Marine Sciences and Technology, Department of Fisheries and Processing Technology, \\ https://orcid.org/0000-0003-3015-8688 \\ Çanakkale Onsekiz Mart University, 17100, Çanakkale, Turkey \\ ${ }^{3}$ Central Fisheries Research Institute, Department of Food Technology, 61100, Trabzon, Turkey \\ https://orcid.org/0000-0001-5486-7425
}

\section{How to cite this paper:}

Çankırılıgil, E.C., Berik, N. \& Erbay, E.A. (2020). Optimization of hydrolyzation procedure for amino acid analysis in fish meat with HPLC-DAD by Response Surface Methodology (RSM). Ege Journal of Fisheries and Aquatic Sciences, 37(2), 113-123. DOI: 10.12714/egejfas.37.2.01

Abstract: In this research, with the aim of maximizing amino acid content by different hydrolyzation procedures of fish meat were carried out and analysed with high performance liquid chromatography (HPLC) equipped with diode array detector (DAD). Response surface methodology (RSM) was used to determine factors that used in the experiments. The RSM suggested 16 different hydrolyzation trials between the ranges of normality as $3 \mathrm{~N}-8 \mathrm{~N}$, temperature as $90^{\circ} \mathrm{C}$ $110^{\circ} \mathrm{C}$ and duration as $12-24$ hours were run. In the following, hydrolysed samples were analysed with HPLC-DAD and obtained data were evaluated with Box-Behnken method in RSM. Our results show that, the most effective experiment was found as hydrolysing by $3.79 \mathrm{~N}$ at $110^{\circ} \mathrm{C}$ in 24 hours for total amino acid content as well as maximized essential amino acids with 0.981 desirability. For sensitive ones, hydrolysing in $3.42 \mathrm{~N}$ at $106.8^{\circ} \mathrm{C}$ in 12.02 hours was found as most effective with maximized Asn, GIn and Trp with 0.849 desirability.

Keywords: Amino acid, Box-Behnken, seafood, pre-treatment, response surface methodology, hydrolyzation

Öz: Bu çalışmada; diyot dedektörü (DAD) donanımlı yüksek performansı likit kromatografi (HPLC) ile balık etinde gerçekleştirilen amino asit analizinde, amino asit miktarını maksimize etmek için farkı hidrolizasyon prosedürleri gerçekleştirilmiştir. Deneylerde kullanılan faktörleri belirlemek için yanıt yüzey metodu (RSM) kullanılmıştır 16 adet farklı hidrolizasyon deneyi RSM ile kurulmuş olup, $3 \mathrm{~N}-8 \mathrm{~N}$ arasındaki normalite değerleri, $90^{\circ} \mathrm{C}-110^{\circ} \mathrm{C}$ arasındaki sıcaklık değerleri ve 12-24 saat arasındaki süre değerleri dikkate alınmıştır. Elde edilen hidrolizatlar HPLC-DAD ile analiz edilmiş olup elde edilen veri RSM'deki Box-Behnken metoduna göre değerlendirilmiştir. Sonuçlara göre; toplam ve esansiyel amino asitler için en efektif hidrolizasyon metodu 3,29 normalitede, $110^{\circ} \mathrm{C}$ sıcaklıkta, 24 saat olarak belirlenmiş olup istenilebilirlik değeri 0,981 olarak tespit edilmiştir. Hassas amino asitler için ise; 3,42 normalitede, $106,8^{\circ} \mathrm{C}$ sıcaklıkta, 12,02 saat süre Asn, Gln ve Trp için maksimum değerleri vermiş olup istenilebilirlik değeri 0,849 olarak tespit edilmiştir.

Anahtar kelimeler: Amino asit, Box-Behnken, su ürünleri, ön işlem, yanıt yüzey metodu, hidrolizasyon

\section{INTRODUCTION}

Fish and other seafood are ideal food sources for a healthy diet (Hosomi et al., 2012) with high composition of omega 3 fatty acids (Musarskaya et al., 2018), some beneficial nutrients (Biesalski, 2005) low carbohydrate content (Krzynowek \& Murphy, 1987) and high quality proteins (Tahergorabi \& Hosseini, 2018). That protein content has biologically important (Köksal \& Özel, 2008) and well-balanced amino acid composition (Lund, 2013) as well as rich in terms of essential amino acids (Çankırılıgil \& Berik, 2017) which are fundamental for humans (Hou et al., 2015). Essential amino acids are plays such roles in metabolism just as protein synthesis, hormonal secretions, gene expression and cell signalling (Wu, 2009). Besides, non-essentials also contribute to body growth and health (Wu et al., 2013) along with essentials ones.
Considering these benefits, several studies that carried out on amino acid composition of various fish species. Thus, determination techniques of amino acids had gained importance parallel with such studies with the aim of getting more concise results. Despite the fact that, developing several well-designed analyse methods as rapid and accurate, these methods can be as good as the applied hydrolyzation procedure of samples scarcely due to severe conditions of hydrolyzation that caused degradation of amino acid content. Conventional hydrolyzation procedures are based on the digesting of fish meat with hydrochloric acid having high normality at high temperature for hours in drying oven. However, these factors affects each amino acids with different ways and some of them can be degraded and should be welloptimized. 
The optimization of experimental design is very important when the analytical procedures are developed and validated (Vera et al., 2014). Response surface methodology (RSM) as an optimization tool for analytical methods (Bezerra et al., 2008) and using for optimization of all chemical and biochemical processes (Baş \& Boyacl, 2007). RSM is using an empirical model building with considering relationships between independent variables and data that obtained by mathematical and statistical techniques from conducted experiments (Alvarez, 2000; Said Mohamad \& Mohamed Amin, 2015) which is much more time saving than conventional designing methods (Widyaningsih et al., 2018). In this research, RSM was used to specify optimum conditions for pretreatment of amino acid analysis. Before the applying RSM, the experimental design should be specified by choosing the factors that directly affect to responses (Hwang et al., 2016).

The aim of this study is to maximize essential amino acids and reducing losses of non-essential amino acids with applying different ranges of normality, temperature and duration times in the hydrolyzation procedure of fish meat. Furthermore, the composition of some vulnerable amino acids such as tryptophan (Trp), glutamine (Gln), asparagine (Asn) are decrease more than others when they exposed to high temperature and low pH (Varlık et al., 2004) whereas causing an increase on aspartic acid and glutamic acid (Dong et al., 2005), inversely. Also, the optimum conditions for aforementioned amino acids were determined. Ultimately, two suggested hydrolyzation conditions by the RSM were performed as pre-treatment for both essential amino acids and vulnerable ones.

\section{MATERIAL AND METHODS}

\section{Chemical, solutions and consumables}

Hydrochloric acid fuming $\% 37(\mathrm{HCl})$, sodium phosphate dibasic solution $\left(\mathrm{Na}_{2} \mathrm{HPO}_{4}\right)$, sodium hydroxide $(\mathrm{NaOH})$, methanol ( $\mathrm{MeOH}$; $\mathrm{GC}$ grade) and acetonitrile (ACN; GC grade) were purchased from Merck. Borate buffer, o-phthalaldehyde reagent (OPA), 9-fluorenylmethyl chloroformate reagent (FMOC), amino acid standard solutions (mix of L-alanine, Larginine, L-aspartic acid, L-cystine, L-glutamic acid, glycine, Lhistidine hydrochloride monohydrate, L-isoleucine, L-leucine, L-lysine hydrochloride, L-methionine, L-phenylalanine, Lproline, L-serine, L-threonine, L-tyrosine, L-valine stored in $0.1 \mathrm{~N} \mathrm{HCl}$ with different dosages as $1 \mathrm{nmol}, 250 \mathrm{pmol}, 100 \mathrm{pmol}$, 25pmol and 10pmol) and extended amino acid standards for sensitive ones such as L-glutamine, L-asparagine, Ltryptophan and L-4-hydroxyprolin in the form of powder were obtained from Agilent Technologies. Water purified (18.1 megaohm purity) with Thermo Scientific Nanopure. Amino acid

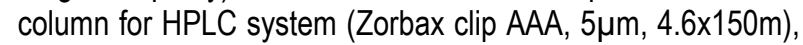
$1.5 \mathrm{ml}$ amber vials with politetrafloroetilen caps (PTFE) and syringe filters $(0.45 \mu \mathrm{m})$ were also purchased from Agilent Technologies.

\section{Fish material}

In this research, rainbow trout (Oncorhynchus mykiss) was preferred as fish material for the purpose of the amino acid studies carried out with this species are very common and discussion were done considering such studies. Trouts were obtained from Central Fisheries Research Institute operated in Trabzon, Turkey and 50 individuals which are $250 \mathrm{~g}$ each were used. Firstly, trouts were washed and deskinned. Fillets were homogenized with Stomacher 400 Circulator in $300 \mathrm{rpm}$ and samples were stored in $+2^{\circ} \mathrm{C}$ for further stages.

\section{Experimental design}

In this study, the effects of three independent variables such as normality, temperature and time on amino acid content of fish meat were evaluated. Thus, the Box-Behnken analysis of response surface methodology (RSM) was used for experimental design. In this method, the most effective values of factors affecting responses were determined for selected responses. The maximum and minimum values of these factors were determined according to preliminary results and upper or lower values of these factors caused some false and irregularities in amino acid analysis due to excessive or insufficient hydrolysing. The values were coded as $-1,0$ and +1 for minimum values, mean values and maximum values, respectively (Table 1). In the values ranging $1 \mathrm{~N}-3 \mathrm{~N}, 70^{\circ} \mathrm{C}$ $90^{\circ} \mathrm{C}$ and 8-12 hours samples were not completely digested. Above the $8 \mathrm{~N}, 110^{\circ} \mathrm{C}$ and 24 hours caused losses of some amino acids completely. For this reason, the factors were selected as normality ranging from $3 \mathrm{~N}$ to $8 \mathrm{~N}$, temperature ranging from $90^{\circ} \mathrm{C}$ to $110^{\circ} \mathrm{C}$ and duration ranging from 12 to 24 hours. Besides, content of total amino acids (TAA), total essential amino acids (TEAA), threonine (Thr), valine (Val), methionine (Met), phenylalanine (Phe), isoleucine (Iso), leucine (Leu), lysine (Lys), tryptophan (Trp), asparagine (Asn), aspartic acid (Asp), glutamine (Gln), glutamic acid (Glu), serine (Ser), glycine (Gly), histidine (His), alanine (Ala), tyrosine (Tyr), cysteine (Cys), hydroxyproline (Hyp) were selected as responses individually. Thus, according to Box-Behnken design, 16 experiments having differences in the combination of these factors were determined. In the following, $1 \mathrm{gram}$ of homogenised fish meat and $10 \mathrm{ml} \mathrm{HCl}$ which have different normalities put on autoclave bottle enduring high temperature and pressure were digested in drying oven in varied temperatures and duration time in accordance with design matrix. Box-Behnken design matrix of the dependent variables was shown in Table 1. All experiments were replicated 3 times $(n=3)$. 
Table 1. Box-Behnken design matrix of pre-treatment of fish meat for amino acid analyses

\begin{tabular}{|c|c|c|c|c|}
\hline $\begin{array}{l}\text { Design } \\
\text { Order }\end{array}$ & $\begin{array}{c}\text { Temperature } \\
\left({ }^{\circ} \mathbf{C}\right) \\
\mathbf{X}^{1}\end{array}$ & $\begin{array}{c}\text { Normality } \\
(\mathbf{N}) \\
\mathbf{X}^{2}\end{array}$ & $\begin{array}{c}\text { Duration } \\
\text { (hour) } \\
\mathbf{X}^{3}\end{array}$ & $\begin{array}{c}\text { Responses } \\
\mathbf{Y}\end{array}$ \\
\hline $\mathbf{1}$ & -1 & -1 & 0 & - \\
\hline $\mathbf{2}$ & 1 & -1 & 0 & - \\
\hline $\mathbf{3}$ & -1 & 1 & 0 & - \\
\hline $\mathbf{4}$ & 1 & 1 & 0 & - \\
\hline $\mathbf{5}$ & -1 & 0 & -1 & - \\
\hline $\mathbf{6}$ & 1 & 0 & -1 & - \\
\hline $\mathbf{7}$ & -1 & 0 & 1 & - \\
\hline $\mathbf{8}$ & 1 & 0 & 1 & - \\
\hline $\mathbf{9}$ & 0 & -1 & -1 & - \\
\hline $\mathbf{1 0}$ & 0 & 1 & -1 & - \\
\hline $\mathbf{1 1}$ & 0 & -1 & 1 & - \\
\hline $\mathbf{1 2}$ & 0 & 1 & 1 & - \\
\hline $\mathbf{1 3}$ & 0 & 0 & 0 & - \\
\hline $\mathbf{1 4}$ & 0 & 0 & 0 & - \\
\hline $\mathbf{1 5}$ & -1 & -1 & -1 & - \\
\hline 16 & 1 & 1 & 1 & - \\
\hline
\end{tabular}

*TAA, TEAA, Ala, Asn, Asp, Cys, Gln, Glu, Gly, His, Hyp, Ile, Leu, Lys, Met, Phe, Ser, Thr, Trp, Tyr, Val were selected as responses, individually.

\section{Amino acid analyses}

Subsequent to hydrolysing procedure, obtained samples were filtered by syringe filter $(0.45 \mu \mathrm{m})$, diluted as $10^{-1}$ with purified water and finally they stored in $1.5 \mathrm{ml}$ amber vials equipped with PTFE caps for the amino acid analysis. Amino acid analyses were carried out with Agilent HPLC Infinity II system equipped with diode array detector (DAD) and autosampler. Amino acid analyses were done according to the

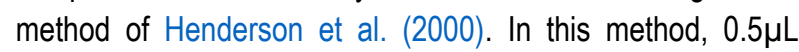
sample was drawn from vial with an automatic sampler and it was derivatized with borate buffer, OPA and FMOC reagents. Subsequent to derivatization, samples were injected to the system individually. Separation of amino acids was carried out by Zorbax Eclipse AAA amino acid column at $40^{\circ} \mathrm{C}$ in gradual mobile phase which are mix of $40 \mathrm{mM} \mathrm{Na}_{2} \mathrm{HPO}_{4}(\mathrm{~A})$ adjusted to $7.8 \mathrm{pH}$ with $10 \mathrm{~N} \mathrm{NaOH}$ and $\mathrm{MeOH}: \mathrm{ACN}: \mathrm{H}_{2} \mathrm{O}(\mathrm{B})$ in the ratio of 45\%:45\%:10\% with $2 \mathrm{~mL} / \mathrm{min}$ flow rate, approximately for 26 minutes. Gradient stages of mobile phase were applied as A:100\%, B:0\%; A:43\%, B:57\%; A:0\%, B:100\%; A:0\%, B:100\%; $A: 100 \%, B: 0 \%$ in $1.9 \mathrm{~min}, 18.1 \mathrm{~min}, 18.6 \mathrm{~min}, 22.3 \mathrm{~min}, 23.2 \mathrm{~min}$, respectively. Detection was done in two different wavelengths in 338nm, 10nm bandwidth for OPA-amino acids and $262 \mathrm{~nm}$, $16 \mathrm{~nm}$ bandwidth for FMOC-amino acids. All samples were analysed for 3 times $(n=3)$. Obtained results were calibrated automatically and expressed as $\mathrm{g} / 100 \mathrm{~g}$.

\section{Data evaluation}

Obtained results from amino acid analysis were written in response column in Box-Behnken design matrix and evaluated with Design Expert 7.16 software. All models were formulated in compliance with results along with the significance of models and lack of fit which were evaluated for all responses as TAA, TEAA, Ala, Asn, Asp, Cys, Gln, Glu, Gly, His, Hyp, Ile, Leu, Lys, Met, Phe, Ser, Thr, Trp, Tyr and Val. Besides, along with responses of TAA and TEAA, they were also evaluated with the sum of mentioned amino acids. Finally, optimum values for to get maximal total amino acid content as well as essential amino acids and maximized vulnerable amino acids were determined considering the results of 16 experiments. The used functions of models were given below.

$y=\beta_{0}+\sum \beta_{i} X_{i} \quad$ (Linear model)

$y=\beta_{0}+\sum \beta_{i} X_{i}+\sum \beta_{i j} X_{i} X_{j} \quad$ (Two factor interaction model)

$y=\beta_{0}+\sum \beta_{i} X_{i}+\sum \beta_{i j} X_{i} X_{j}+\sum \beta_{i i} X_{i}^{2} \quad$ (Quadratic model)

Where $y$ is one of the responses, $\beta_{0}$ is the regression intercept, $X$ symbols are independent variables, $\beta_{i}$ is coefficient of the linear parameters, $\beta_{i j}$ is coefficient of interaction between factors, and $\beta_{i i}$ is the coefficient of the quadratic parameters (Davarnejad et al., 2018; Nadarajan et al., 2018).

Differences among amino acid composition of all experiments were determined by one-way analysis of variance one-way ANOVA in SPSS 12 after testing the homogeneity of the data (Levene test). Results were expressed as mean $\pm S D$ $(n=9)$ and significance level was set as $P \leq 0.05$ (Zar, 1999).

Achieved optimum values of factors for both total amino acids and vulnerable ones were expressed as optimization 1 $\left(\mathrm{O}_{1}\right)$ and optimization $2\left(\mathrm{O}_{2}\right)$, respectively. In the evaluation of $\mathrm{O}_{1}$, the essential amino acids except tryptophan were selected as for getting maximum along with other amino acids. In the second one $\left(\mathrm{O}_{2}\right)$, an additional optimization procedure was carried out for getting maximized some special amino acids that show variations in quantity with high temperature and low $\mathrm{pH}$ such as Trp, Asn, GIn. With these extreme conditions, Asn and Gln can be transformed to Asp and Glu, respectively. Therefore; Asp, Asn, Gln and Glu were evaluated separately along with Trp which is amongst most vulnerable ones. Ultimately, these two optimization procedures were applied as $17^{\text {th }}$ and $18^{\text {th }}$ experiments and amino acid composition of these experiments was determined and compared to previous runs.

\section{RESULTS AND DISCUSSION}

According to experiments, linear model was applied for TAA, TEAA, Glu, Ser, Gly, Thr, Tyr, Val, Met, Trp, Iso, Leu; two factor interaction (2FI) model was applied for Asp, Asn, Gln, 
His, Ala, Lys; and quadratic model was applied Cys and Hyp. The final equations of coded factors for models are;

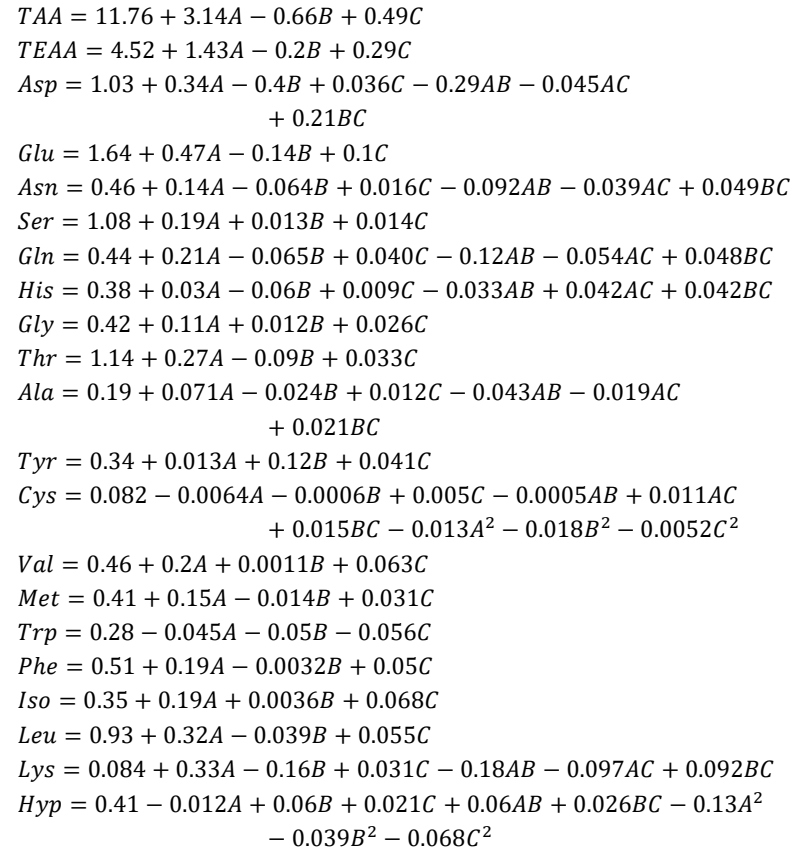

Among these models, linear models of TAA and TEAA were found significant with a very low pure error. Analysis of variance for the responses of total amino acids and essential amino acids were shown in Table 2. The response surface models of amino acids and essential amino acids were also shown in Figure 1.
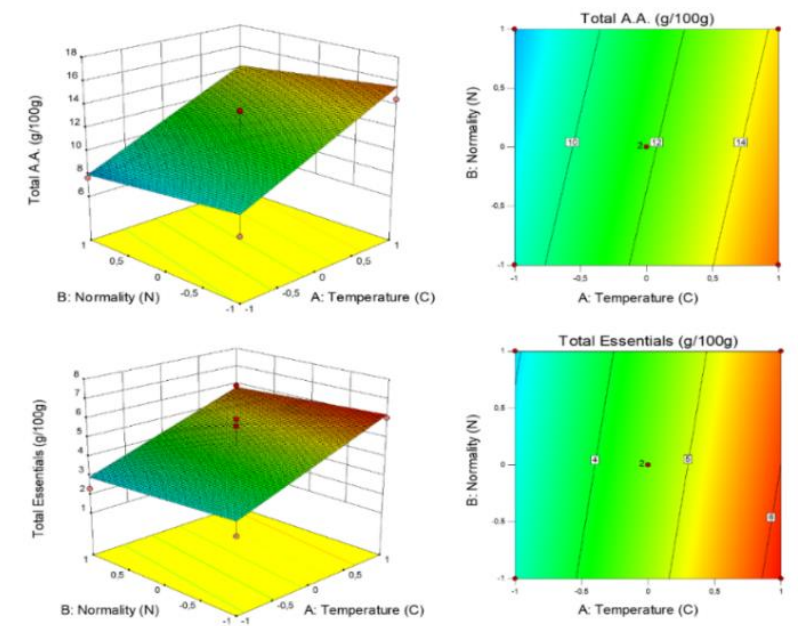

Figure 1. Response surface plots for total amino acids and essential amino acids

Table 2. Analysis of variance for models of total amino acids and essential amino acids

\begin{tabular}{|c|c|c|c|c|c|c|}
\hline Total A.A. & SS & df & MS & F Value & $\mathrm{p}$-value & \\
\hline Linear Model & 115.02 & 3 & 38.34 & 5.03 & 0.0143 & significant \\
\hline A:Temperature & 112.54 & 1 & 112.54 & 14.76 & 0.0018 & \\
\hline B:Normality & 4.87 & 1 & 4.87 & 0.64 & 0.4377 & \\
\hline C:Time & 2.79 & 1 & 2.79 & 0.37 & 0.5552 & \\
\hline Residual & 106.75 & 14 & 7.63 & & & \\
\hline Lack of Fit & 106.75 & 13 & 8.21 & 2830.61 & 0.0147 & significant \\
\hline Pure Error & 0.0029 & 1 & 0.00 & & & \\
\hline Total E.A.A. & SS & df & MS & F Value & p-value & \\
\hline Linear Model & 24.38 & 3 & 8.13 & 5.59 & 0.0099 & significant \\
\hline A:Temperature & 23.42 & 1 & 23.42 & 16.1 & 0.0013 & \\
\hline B:Normality & 0.44 & 1 & 0.44 & 0.3 & 0.5906 & \\
\hline C:Time & 0.95 & 1 & 0.95 & 0.65 & 0.4329 & \\
\hline Residual & 20.37 & 14 & 1.45 & & & \\
\hline Lack of Fit & 20.37 & 13 & 1.57 & 7340.16 & 0.0091 & significant \\
\hline Pure Error & 0.0002 & 1 & 0.0002 & & & \\
\hline
\end{tabular}

*SS: Sum of squares, df: Degrees of freedom, MS: Mean squares.

${ }^{* *}$ Tryptophan was evaluated separately apart from the essential amino acids due to sensitive high temperature and low pH. (A.A.: Amino acids, E.A.A.: Essential amino acids).

When the essential amino acids evaluated individually, all models except tryptophan were found significant. The linear model of methionine was determined as significant, in spite of the model's lack of fit was found as not significant. Analysis of variance for the responses of some amino acids were shown in Table 3. 
Table 3. Analysis of variance for some models of amino acids

\begin{tabular}{|c|c|c|c|c|c|c|}
\hline Response & SS & df & MS & F Value & p-value & \\
\hline THR (Linear model) & 0.86 & 3 & 0.29 & 3.41 & 0.0474 & significant \\
\hline Lack of Fit & 1.17 & 13 & 0.090 & 296.10 & 0.0455 & significant \\
\hline VAL (Linear model) & 0.51 & 3 & 0.17 & 7.99 & 0.0024 & significant \\
\hline Lack of Fit & 0.30 & 13 & 0.023 & 348.25 & 0.0419 & significant \\
\hline MET (Linear model) & 0.28 & 3 & 0.095 & 6.37 & 0.0060 & significant \\
\hline Lack of Fit & 0.21 & 13 & 0.016 & 100.82 & 0.0778 & not significant \\
\hline PHE (Linear model) & 0.45 & 3 & 0.15 & 5.62 & 0.0097 & significant \\
\hline Lack of Fit & 0.37 & 13 & 0.029 & 306.86 & 0.0447 & significant \\
\hline ISO (Linear model) & 0.51 & 3 & 0.17 & 9.46 & 0.0011 & significant \\
\hline Lack of Fit & 0.25 & 13 & 0.019 & 714.55 & 0.0293 & significant \\
\hline LEU (Linear model) & 1.20 & 3 & 0.40 & 4.96 & 0.0150 & significant \\
\hline Lack of Fit & 1.13 & 13 & 0.087 & 493.23 & 0.0352 & significant \\
\hline LYS (2FI model) & 1.52 & 6 & 0.25 & 6.40 & 0.0042 & significant \\
\hline Lack of Fit & 0.43 & 10 & 0.043 & 4074.21 & 0.0122 & significant \\
\hline ASP (2FI model) & 2.91 & 6 & 0.49 & 6.58 & 0.0037 & significant \\
\hline Lack of Fit & 0.81 & 10 & 0.081 & 25311.75 & 0.0049 & significant \\
\hline GLU (Linear model) & 4.20 & 3 & 1.40 & 4.56 & 0.0198 & significant \\
\hline Lack of Fit & 4.29 & 13 & 0.33 & 32.86 & 0.1358 & not significant \\
\hline
\end{tabular}

* SS: Sum of squares, df: Degrees of freedom, MS: Mean squares

The most appropriate model was selected as $2 \mathrm{FI}$ model via Box-Behnken design matrix in Design Expert 7.16 software for asparagine and glutamine. According to models, the lack of fit parameters were found not significant instead of models found as significant same as glutamic acid (Table 3). As we mentioned before, asparagine and glutamine are sensitive to high temperature and they can transform to aspartic acid and glutamic acid in the presence of heat and low pH (Dong et al., 2005).
However; Asp, Glu, Asn and Gln are increasing together with the heat and $\mathrm{pH}$ in spite of this transforming process. Our results show that, asparagine and glutamine are increasing till the some point due to degradation of proteins to amino acids by digestion process. That's the reason why the models have shown similarities for independent variables contrary to expectations. Analysis of variance for the responses of asparagine and glutamine shown in Table 4. The response surface models of Gln and Asn were shown in Figure 2.

Table 4. Analyses of variance for models of asparagine and glutamine

\begin{tabular}{|c|c|c|c|c|c|c|}
\hline ASN & SS & df & MS & F Value & $\mathrm{p}$-value & \\
\hline 2FI Model & 0.28 & 6 & 0.047 & 4.66 & 0.0135 & significant \\
\hline A:Temperature & 0.2 & 1 & 0.2 & 20.17 & 0.0009 & \\
\hline B:Normality & 0.042 & 1 & 0.042 & 4.17 & 0.0658 & \\
\hline C:Time & 0.0026 & 1 & 0.0026 & 0.26 & 0.6185 & \\
\hline$A B$ & 0.058 & 1 & 0.058 & 5.75 & 0.0354 & \\
\hline$A C$ & 0.0094 & 1 & 0.0094 & 0.94 & 0.3542 & \\
\hline$B C$ & 0.016 & 1 & 0.016 & 1.63 & 0.2276 & \\
\hline Residual & 0.11 & 11 & 0.01 & & & \\
\hline Lack of Fit & 0.11 & 10 & 0.011 & 191.02 & 0.0563 & not significant \\
\hline Pure Error & 0.0001 & 1 & 0.0001 & & & \\
\hline GLN & SS & df & MS & F Value & $\mathrm{p}$-value & \\
\hline 2FI Model & 0.59 & 6 & 0.099 & 6.29 & 0.0045 & significant \\
\hline A:Temperature & 0.46 & 1 & 0.46 & 29.25 & 0.0002 & \\
\hline B:Normality & 0.044 & 1 & 0.044 & 2.8 & 0.1224 & \\
\hline C:Time & 0.017 & 1 & 0.017 & 1.11 & 0.3154 & \\
\hline$A B$ & 0.099 & 1 & 0.099 & 6.27 & 0.0293 & \\
\hline$A C$ & 0.019 & 1 & 0.019 & 1.18 & 0.3012 & \\
\hline$B C$ & 0.016 & 1 & 0.016 & 0.99 & 0.3414 & \\
\hline Residual & 0.17 & 11 & 0.016 & & & \\
\hline Lack of Fit & 0.17 & 10 & 0.017 & 33.74 & 0.1333 & not significant \\
\hline Pure Error & 0.0005 & 1 & 0.0005 & & & \\
\hline
\end{tabular}

* SS: Sum of squares, df: Degrees of freedom, MS: Mean squares 

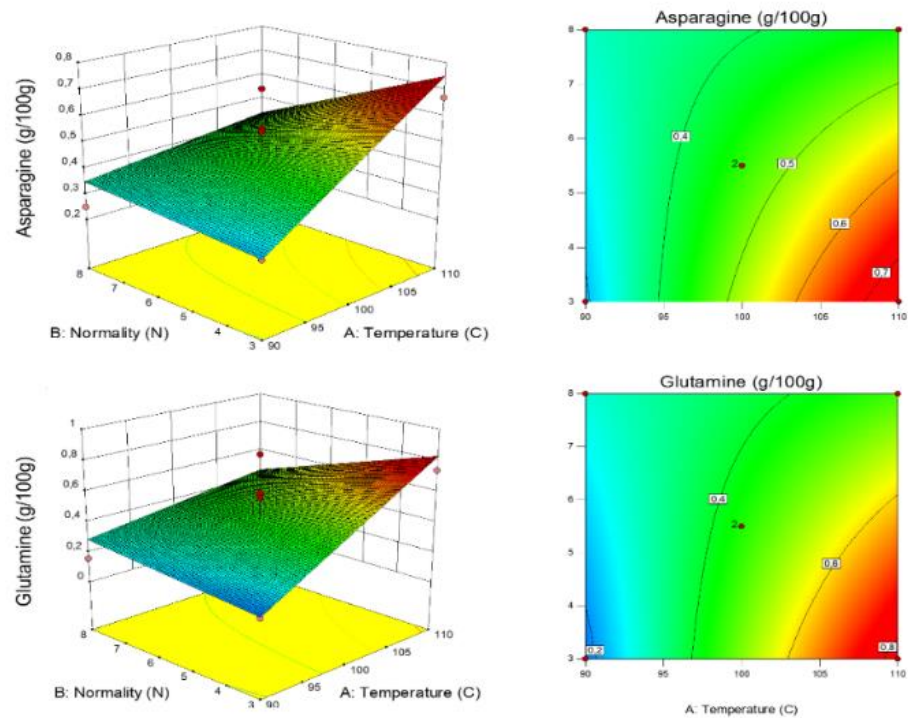

Figure 2. Response surface plots for asparagine and glutamine

Tryptophan is vulnerable for high temperatures and low $\mathrm{pH}$ (Marinho et al., 2015; Varlık et al., 2004) and the most intense losses occur at $100^{\circ} \mathrm{C}$ in the $\mathrm{pH}$ ranging 2 to 7 (Cuq \& Firedman, 1989). Thus, it can be easily degraded during any pre-treatment based on digestion with the acidic environment at high temperatures. So, with the aim of more concise results, tryptophan was evaluated separately from the others due to this unique structure.

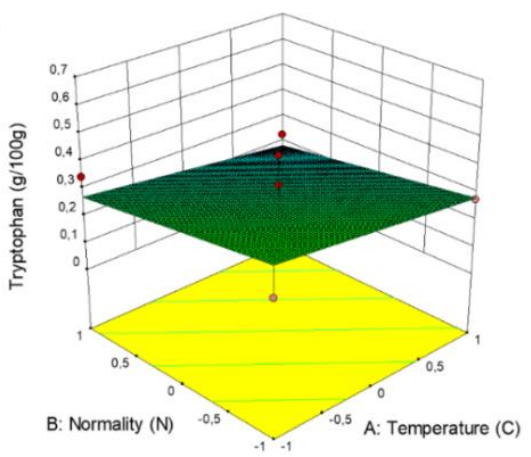

Linear model was applied for tryptophan which is determined via Box-Behnken design matrix. According to results, neither model nor lack of fit parameters found significant. According to our results, its severe conditions that directly changes the composition of tryptophan have an effect on the model. Analysis of variance for the response and surface response plot of tryptophan were shown in Table 5 and Figure 3.

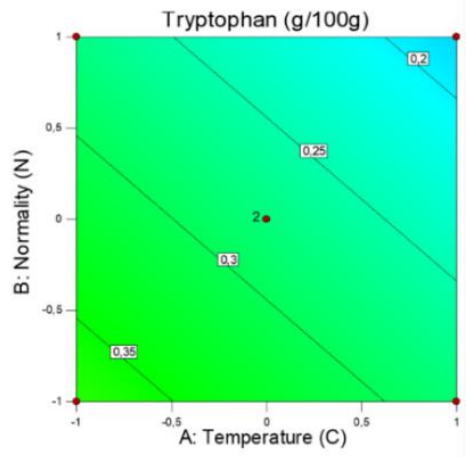

Figure 3. Response surface plot of tryptophan

Table 5. Analysis of variance for the model of tryptophan

\begin{tabular}{|c|c|c|c|c|c|c|}
\hline TRP & SS & df & MS & F Value & $\mathrm{p}$-value & \\
\hline Linear Model & 0.11 & 3 & 0.037 & 1.32 & 0.3062 & not significant \\
\hline A:Temperature & 0.023 & 1 & 0.023 & 0.82 & 0.3818 & \\
\hline B:Normality & 0.028 & 1 & 0.028 & 1 & 0.3341 & \\
\hline C:Time & 0.036 & 1 & 0.036 & 1.28 & 0.2768 & \\
\hline Residual & 0.4 & 14 & 0.028 & & & \\
\hline Lack of Fit & 0.39 & 13 & 0.03 & 5.29 & 0.3292 & not significant \\
\hline Pure Error & 0.0057 & 1 & 0.0057 & & & \\
\hline
\end{tabular}

* SS: Sum of squares, df: Degrees of freedom, MS: Mean squares 
The obtained results were evaluated with numerical optimization option in Design Expert 7.16 software. In numerical optimization, responses of all amino acids which is amino acid content (y) in our study can be selected as "maximum", "minimum", "in the range" and "exclude". With this selection, the amounts of amino acids can be maximized or minimized with regard to factors $\left(X^{1}, X^{2}\right.$ and $\left.X^{3}\right)$ which are values of normality, temperature and duration in this study. In optimization one $\left(\mathrm{O}_{1}\right)$, essential amino acids except tryptophan were selected as "maximum" and the rest of them selected as "in the range" choice with the aim of getting maximum of essential amino acids along with moderate non-essential amino acids. According to results, the most reliable solution having the highest desirability $(0.981)$ specified as hydrolysing in $3.79 \mathrm{~N}$ at $110^{\circ} \mathrm{C}$ in 23.98 hours. Desirability ramp for optimization procedure 1 shown in Figure 4.

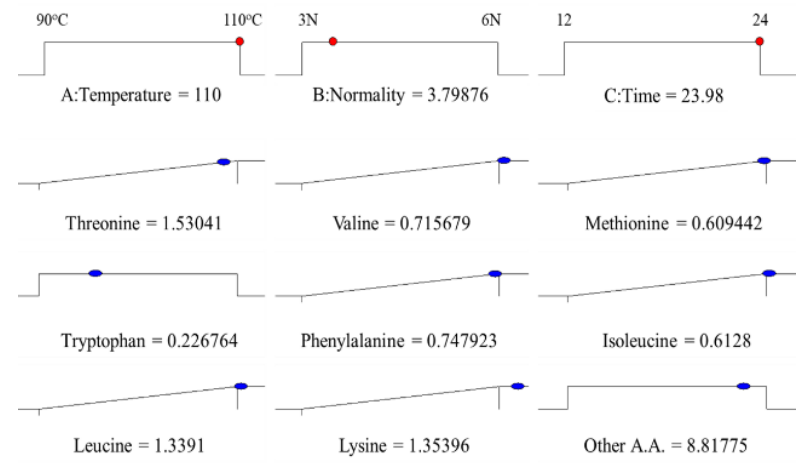

Figure 4. Optimized hydrolyzation procedure for essential amino acids. All essential amino acids except of tryptophan were selected as "maximum", the sum of remain amino acids and tryptophan selected as "in the range"

In optimization two $\left(\mathrm{O}_{2}\right)$, tryptophan, asparagine and glutamine were selected as "maximum" and aspartic acid and glutamic acid selected as "in the range" choice with the aim of getting maximum of sensitive ones along with moderate AspGlu. According to results, the most convenient solution having the highest desirability $(0.849)$ specified as hydrolysing in 3.42 $\mathrm{N}$ at $106.8^{\circ} \mathrm{C}$ in 12.02 hours. Desirability ramp for optimization procedure 2 shown in Figure 5.

After the optimization, achieved two optimizations procedure were applied and compared to previous runs. According to results; glutamine, serine, histidine, threonine, tyrosine, valine, phenylalanine, Isoleucine, leucine, lysine and total amino acids were found highest statistically in the optimization $1\left(\mathrm{O}_{1}\right)$ among all experiments.

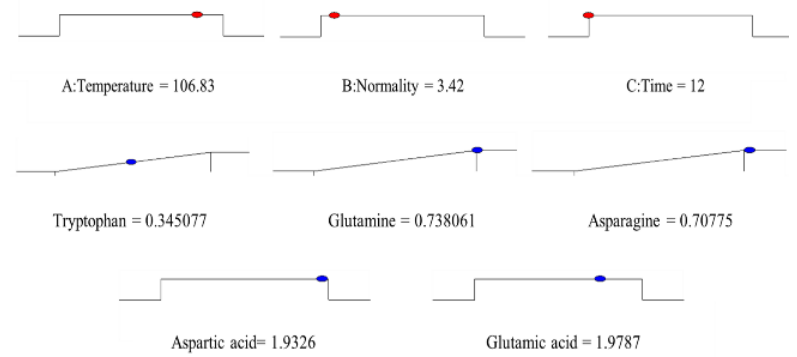

Figure 5. Optimized digestion procedure for sensitive amino acids. While tryptophan, asparagine and glutamine were selected as maximum, aspartic acid and glutamic acid were selected as in the range

Only methionine was detected as the second highest in $\mathrm{O}_{1}$ consonant with their model. Considering the importance of the essential amino acids along with non-essentials which are supports growth and maintaining health (Hou et al., 2015; Lund, 2013; Wu, 2009; Wu et al., 2013), the hydrolyzation procedure $1\left(\mathrm{O}_{1}\right)$ can be suggested as a pre-treatment for amino acid analyses in the fish meat.

Asparagine and glutamine are vulnerable to high temperature and they can transform to aspartic and glutamic acids by high temperature. Several researchers are either not analysed asparagine and glutamine (Chen et al., 2007; Kang et al., 2014; Mohanty et al., 2014; Unusan, 2007) or they stated that asparagine and glutamine are very low or none in the fish meat (Boonyoung et al., 2012; Dong et al., 2005; Rebolé et al., 2015; Sarma et al., 2013) contrary to aspartic acid and glutamic acid which are found highest amino acids, often (Özden, 2005; Park et al., 2006). Reason for this, asparagine and glutamine are directly affected by the severe conditions of the digestion process. In this research, after the optimization $2\left(\mathrm{O}_{2}\right)$, the highest asparagine and glutamine were detected with moderate aspartic acid and glutamic acid.

Tryptophan is also not detected in most of the studies related to various fish species (Boonyoung et al., 2012; Galla et al., 2012; Joshi et al., 2017; Oluwaniyi et al., 2010). Despite the fact that the tryptophan model is not significant, the second pre-treatment suggestion $\left(\mathrm{O}_{2}\right)$ is more successful than other experiments. In this research, one of the main aims is to determine the rapid and precise digestion procedure for amino acid analysis aforementioned before. For this reason, optimization 2 can be used for total determination of sensitive amino acids just like tryptophan, asparagine, glutamine along with aspartic acid and glutamic acid.

For more concise and precise results for tryptophan individually, other digestion procedures based on alkaline digestion methods (Bech-Andersen, 1991; Nielsen \& Hurrell, 1984) or enzymatic hydrolysis (Kurozawa et al., 2008; Nilsang et al., 2005) can be used. The obtained amino acid results of the experiments were shown in Table 6. 
Çankirlıgil et al., Ege Journal of Fisheries and Aquatic Sciences, 37(2), 113-123 (2020)

Table 6. Amino acid composition of fish meat according to conducted experiments (g/100g)

\begin{tabular}{|c|c|c|c|c|c|c|c|c|c|c|c|c|c|c|c|c|c|c|}
\hline D.O. & 1 & 2 & 3 & 4 & 5 & 6 & 7 & 8 & 9 & 10 & 11 & 12 & 13 & 14 & 15 & 16 & $0_{1}$ & $\mathrm{O}_{2}$ \\
\hline ASP & $1.04 \mathrm{e}$ & $1.93^{\mathrm{a}}$ & $0.35^{h}$ & $0.98^{\mathrm{e}}$ & $0.63 \mathrm{~g}$ & $1.15^{\mathrm{e}}$ & $0.79^{f}$ & $1.19 \mathrm{e}$ & $1.79^{b}$ & $0.41^{\mathrm{h}}$ & $1.66^{c}$ & $0.73^{f}$ & $1.14 \mathrm{e}$ & $1.14 \mathrm{e}$ & $0.74^{f}$ & $0.81^{\dagger}$ & $1.41^{\mathrm{d}}$ & $1.02^{\mathrm{e}}$ \\
\hline$( \pm S E)$ & \pm 0.06 & \pm 0.06 & \pm 0.08 & \pm 0.04 & \pm 0.02 & \pm 0.05 & \pm 0.03 & \pm 0.05 & \pm 0.17 & \pm 0.05 & \pm 0.08 & \pm 0.04 & \pm 0.13 & \pm 0.05 & \pm 0.06 & \pm 0.08 & \pm 0.06 & \pm 0.05 \\
\hline GLU & $1.04^{f}$ & $2.54^{a}$ & 0.689 & $2.0^{1}$ & $1.08^{\mathrm{f}}$ & $2.18^{b}$ & $1.18^{f}$ & $2.24^{\mathrm{ab}}$ & $2.5^{a}$ & $0.92^{\text {fg }}$ & $2.65^{\mathrm{a}}$ & $1.07^{f}$ & $2.02^{c}$ & $2.16^{b}$ & $0.79^{f g}$ & $1.76^{\mathrm{d}}$ & $2.53^{\mathrm{a}}$ & $1.51 \mathrm{e}$ \\
\hline$( \pm S E)$ & \pm 0.03 & \pm 0.22 & \pm 0.02 & \pm 0.06 & \pm 0.05 & \pm 0.04 & \pm 0.06 & \pm 0.10 & \pm 0.26 & \pm 0.12 & \pm 0.15 & \pm 0.11 & \pm 0.22 & \pm 0.06 & \pm 0.06 & \pm 0.13 & \pm 0.04 & \pm 0.04 \\
\hline ASN & $0.29^{f}$ & $0.67^{\mathrm{ab}}$ & $0.25^{f}$ & $0.54^{c}$ & $0.35^{\mathrm{e}}$ & $0.56^{c}$ & $0.38^{\mathrm{e}}$ & $0.52^{c}$ & $0.62^{b}$ & $0.27^{f}$ & $0.60^{\mathrm{b}}$ & $0.36^{\mathrm{e}}$ & $0.55^{c}$ & $0.54 c$ & 0.219 & $0.45^{\mathrm{d}}$ & $0.61^{b}$ & $0.77^{a}$ \\
\hline$( \pm S E)$ & \pm 0.01 & \pm 0.03 & \pm 0.01 & \pm 0.02 & \pm 0.01 & \pm 0.01 & \pm 0.04 & \pm 0.03 & \pm 0.07 & \pm 0.03 & \pm 0.02 & \pm 0.05 & \pm 0.03 & \pm 0.02 & \pm 0.01 & \pm 0.01 & \pm 0.02 & \pm 0.02 \\
\hline SER & $0.84^{\text {ef }}$ & $1.177^{\mathrm{dd}}$ & $0.79^{f}$ & $1.35^{b}$ & $0.87^{e}$ & $1.24 c$ & $0.70^{g}$ & $1.12^{\mathrm{cd}}$ & $1.33^{b}$ & $0.93^{e}$ & $1.28^{c}$ & $1.08^{\mathrm{d}}$ & $1.22^{\mathrm{c}}$ & $1.17^{\mathrm{cd}}$ & 0.719 & $1.23^{c}$ & $1.64^{\mathrm{a}}$ & $1.12^{\mathrm{cd}}$ \\
\hline$( \pm S E)$ & \pm 0.01 & \pm 0.02 & \pm 0.02 & \pm 0.21 & \pm 0.11 & \pm 0.13 & \pm 0.04 & \pm 0.19 & \pm 0.16 & \pm 0.01 & \pm 0.02 & \pm 0.02 & \pm 0.03 & \pm 0.02 & \pm 0.03 & \pm 0.14 & \pm 0.02 & \pm 0.02 \\
\hline GLN & $0.17^{\mathrm{h}}$ & $0.74^{b}$ & $0.16^{h}$ & $0.57^{d}$ & $0.17^{\mathrm{h}}$ & $0.59^{d}$ & 0.249 & $0.56^{d}$ & $0.54^{d}$ & $0.25 \mathrm{~g}$ & $0.66^{c}$ & $0.35^{f}$ & $0.59 \mathrm{~d}$ & $0.56^{d}$ & $0.11 i$ & $0.46^{\mathrm{e}}$ & $0.44 \mathrm{e}$ & $0.81^{a}$ \\
\hline$( \pm S E)$ & \pm 0.01 & \pm 0.02 & \pm 0.03 & \pm 0.02 & \pm 0.01 & \pm 0.01 & \pm 0.02 & \pm 0.03 & \pm 0.06 & \pm 0.03 & \pm 0.01 & \pm 0.06 & \pm 0.05 & \pm 0.00 & \pm 0.01 & \pm 0.02 & \pm 0.01 & \pm 0.03 \\
\hline HIS & $0.41^{\mathrm{b}}$ & $0.49^{a b}$ & $0.27^{\mathrm{d}}$ & $0.42^{b}$ & $0.39^{c}$ & $0.27^{\mathrm{d}}$ & $0.33^{\mathrm{cd}}$ & $0.43^{b}$ & $0.56^{a}$ & $0.29^{c d}$ & $0.49^{\mathrm{ab}}$ & $0.33^{\text {cd }}$ & $0.43^{b}$ & $0.40^{c}$ & $0.41^{b}$ & $0.39 c$ & $0.55^{\mathrm{a}}$ & $0.43^{b}$ \\
\hline$( \pm S E)$ & \pm 0.02 & \pm 0.02 & \pm 0.01 & \pm 0.04 & \pm 0.02 & \pm 0.01 & \pm 0.01 & \pm 0.02 & \pm 0.07 & \pm 0.02 & \pm 0.04 & \pm 0.03 & \pm 0.01 & \pm 0.01 & \pm 0.02 & \pm 0.03 & \pm 0.02 & \pm 0.01 \\
\hline GLY & $0.24^{\mathrm{de}}$ & $0.55^{\mathrm{a}}$ & $0.26^{\text {de }}$ & $0.56^{\mathrm{a}}$ & $0.29^{d}$ & $0.50^{\mathrm{a}}$ & $0.29^{d}$ & $0.49^{a}$ & $0.48^{a}$ & $0.35^{c}$ & $0.51^{\mathrm{a}}$ & $0.43^{b}$ & $0.50^{a}$ & $0.53^{a}$ & $0.19^{e}$ & $0.51^{\mathrm{a}}$ & $0.40^{\mathrm{b}}$ & $0.35^{c}$ \\
\hline$( \pm S E)$ & \pm 0.01 & \pm 0.02 & \pm 0.01 & \pm 0.01 & \pm 0.02 & \pm 0.03 & \pm 0.03 & \pm 0.03 & \pm 0.05 & \pm 0.02 & \pm 0.01 & \pm 0.03 & \pm 0.02 & \pm 0.04 & \pm 0.01 & \pm 0.04 & \pm 0.08 & \pm 0.01 \\
\hline THR & $0.87 \mathrm{e}$ & $1.42^{\mathrm{bc}}$ & $0.61^{\dagger}$ & $1.36^{c}$ & $0.93^{\mathrm{e}}$ & $1.38^{c}$ & $0.94 \mathrm{e}$ & $1.35^{\circ}$ & $1.62^{\mathrm{a}}$ & $0.72^{f}$ & $1.52^{b}$ & $0.91^{\mathrm{e}}$ & $1.36^{c}$ & $1.34^{c}$ & $0.68^{f}$ & $1.18^{d}$ & $1.63^{\mathrm{a}}$ & $1.41^{\mathrm{bc}}$ \\
\hline$( \pm S E)$ & \pm 0.03 & \pm 0.08 & \pm 0.09 & \pm 0.04 & \pm 0.01 & \pm 0.03 & \pm 0.08 & \pm 0.06 & \pm 0.17 & \pm 0.07 & \pm 0.02 & \pm 0.13 & \pm 0.09 & \pm 0.02 & \pm 0.03 & \pm 0.02 & \pm 0.12 & \pm 0.08 \\
\hline ALA & $0.08^{c}$ & $0.28^{a}$ & $0.08^{\mathrm{c}}$ & $0.24^{a}$ & $0.11^{c}$ & $0.24 a$ & $0.13^{b c}$ & $0.24^{a}$ & $0.23^{a}$ & $0.11^{\mathrm{c}}$ & $0.27^{a}$ & $0.14^{b c}$ & $0.25^{a}$ & $0.24^{a}$ & $0.08^{c}$ & $0.18^{b}$ & $0.18^{b}$ & $0.20^{\mathrm{ab}}$ \\
\hline$( \pm S E)$ & \pm 0.01 & \pm 0.01 & \pm 0.01 & \pm 0.01 & \pm 0.01 & \pm 0.02 & \pm 0.01 & \pm 0.01 & \pm 0.03 & \pm 0.01 & \pm 0.01 & \pm 0.03 & \pm 0.03 & \pm 0.01 & \pm 0.01 & \pm 0.01 & \pm 0.02 & \pm 0.02 \\
\hline TYR & $0.17^{\mathrm{de}}$ & $0.17 \mathrm{de}$ & $0.41^{\mathrm{c}}$ & $0.39 c$ & $0.27^{\mathrm{dd}}$ & $0.24^{d}$ & $0.23^{d}$ & $0.34^{\circ}$ & $0.28^{\mathrm{cd}}$ & $0.56^{\mathrm{ab}}$ & $0.23^{d}$ & $0.59^{a}$ & $0.34 c$ & $0.37^{c}$ & $0.14^{\mathrm{e}}$ & $0.65^{a}$ & $0.62^{\mathrm{a}}$ & $0.53^{b}$ \\
\hline$( \pm S E)$ & \pm 0.00 & \pm 0.02 & \pm 0.05 & \pm 0.02 & \pm 0.02 & \pm 0.01 & \pm 0.02 & \pm 0.03 & \pm 0.04 & \pm 0.06 & \pm 0.01 & \pm 0.04 & \pm 0.04 & \pm 0.03 & \pm 0.01 & \pm 0.07 & \pm 0.03 & \pm 0.03 \\
\hline
\end{tabular}




\begin{tabular}{|c|c|c|c|c|c|c|c|c|c|c|c|c|c|c|c|c|c|c|}
\hline CYS & $0.08^{a}$ & $0.03^{c}$ & $0.04^{c}$ & $0.04 \mathrm{c}$ & $0.07 \mathrm{ab}$ & $0.04^{c}$ & $0.04^{c}$ & $0.09 a$ & $0.07 \mathrm{ab}$ & $0.04^{\circ}$ & $0.05^{\mathrm{bc}}$ & $0.06^{\mathrm{abc}}$ & $0.09^{a}$ & $0.08^{a}$ & $0.07 \mathrm{ab}$ & $0.07 \mathrm{ab}$ & $0.05^{b c}$ & $0.06^{a b c}$ \\
\hline$( \pm S E)$ & \pm 0.01 & \pm 0.01 & \pm 0.01 & \pm 0.01 & \pm 0.01 & \pm 0.01 & \pm 0.01 & \pm 0.01 & \pm 0.01 & \pm 0.01 & \pm 0.01 & \pm 0.01 & \pm 0.01 & \pm 0.01 & \pm 0.01 & \pm 0.01 & \pm 0.01 & \pm 0.01 \\
\hline VAL & $0.19^{f}$ & $0.71^{a}$ & $0.17^{\mathrm{fg}}$ & $0.66^{a}$ & $0.23^{\mathrm{e}}$ & $0.59^{b}$ & $0.21 \mathrm{e}$ & $0.67^{a}$ & $0.46^{c}$ & $0.29^{d}$ & $0.63^{\mathrm{ab}}$ & $0.43^{c}$ & $0.61^{\mathrm{ab}}$ & $0.59^{b}$ & $0.15^{9}$ & $0.57^{b}$ & $0.68^{\mathrm{a}}$ & $0.65^{a}$ \\
\hline$( \pm S E)$ & \pm 0.01 & \pm 0.02 & \pm 0.02 & \pm 0.02 & \pm 0.01 & \pm 0.02 & \pm 0.02 & \pm 0.02 & \pm 0.04 & \pm 0.02 & \pm 0.02 & \pm 0.07 & \pm 0.06 & \pm 0.01 & \pm 0.01 & \pm 0.02 & \pm 0.02 & \pm 0.02 \\
\hline MET & $0.19 \mathrm{~g}$ & $0.61^{\mathrm{bc}}$ & 0.179 & $0.55^{c}$ & $0.24^{f}$ & $0.52^{c}$ & $0.26^{f}$ & $0.54^{c}$ & $0.52^{\mathrm{c}}$ & $0.29^{f}$ & $0.57^{\circ}$ & $0.36 \mathrm{e}$ & $0.52^{c}$ & $0.52^{c}$ & $0.14^{h}$ & $0.46^{d}$ & $0.67^{b}$ & $0.76^{a}$ \\
\hline$( \pm S E)$ & \pm 0.01 & \pm 0.02 & \pm 0.02 & \pm 0.02 & \pm 0.01 & \pm 0.02 & \pm 0.03 & \pm 0.02 & \pm 0.05 & \pm 0.03 & \pm 0.03 & \pm 0.05 & \pm 0.04 & \pm 0.01 & \pm 0.01 & \pm 0.02 & \pm 0.02 & \pm 0.06 \\
\hline TRP & $0.26^{\mathrm{e}}$ & $0.28 \mathrm{e}$ & $0.35^{d}$ & $0.23^{f}$ & $0.61^{b}$ & $0.17^{f}$ & $0.06^{\mathrm{h}}$ & $0.15^{\mathrm{fg}}$ & $0.64^{b}$ & $0.09^{h}$ & $0.15^{f g}$ & $0.27 \mathrm{e}$ & $0.32^{\mathrm{de}}$ & $0.43^{c}$ & $0.17^{\dagger}$ & $0.12^{9}$ & $0.10^{h}$ & $0.89^{a}$ \\
\hline$( \pm S E)$ & \pm 0.01 & \pm 0.01 & \pm 0.01 & \pm 0.01 & \pm 0.05 & \pm 0.01 & \pm 0.01 & \pm 0.01 & \pm 0.02 & \pm 0.01 & \pm 0.01 & \pm 0.01 & \pm 0.02 & \pm 0.04 & \pm 0.01 & \pm 0.01 & \pm 0.01 & \pm 0.04 \\
\hline PHE & $0.23^{\mathrm{e}}$ & $0.76^{a}$ & $0.22^{\mathrm{e}}$ & $0.76^{a}$ & $0.28^{d}$ & $0.65^{b}$ & $0.31^{\mathrm{d}}$ & $0.63^{b}$ & $0.61^{b}$ & $0.29^{d}$ & $0.68^{\mathrm{ab}}$ & $0.45^{c}$ & $0.64^{b}$ & $0.63^{b}$ & $0.16^{f}$ & $0.59^{b}$ & $0.74^{a}$ & $0.49 c$ \\
\hline$( \pm S E)$ & \pm 0.01 & \pm 0.02 & \pm 0.04 & \pm 0.03 & \pm 0.01 & \pm 0.01 & \pm 0.03 & \pm 0.05 & \pm 0.06 & \pm 0.04 & \pm 0.03 & \pm 0.07 & \pm 0.08 & \pm 0.01 & \pm 0.02 & \pm 0.03 & \pm 0.02 & \pm 0.02 \\
\hline ISO & $0.06^{\text {hi }}$ & $0.57^{c}$ & $0.08^{\mathrm{h}}$ & $0.48^{\mathrm{d}}$ & $0.08^{h}$ & $0.52^{\mathrm{cd}}$ & $0.12^{g}$ & $0.61^{\circ}$ & 0.34 & $0.22^{f}$ & $0.53^{\text {cd }}$ & $0.35^{\mathrm{e}}$ & $0.51^{\mathrm{cd}}$ & $0.52^{\mathrm{cd}}$ & $0.04 i$ & $0.49^{d}$ & $0.96^{a}$ & $0.81^{b}$ \\
\hline$( \pm S E)$ & \pm 0.01 & \pm 0.02 & \pm 0.02 & \pm 0.03 & \pm 0.01 & \pm 0.03 & \pm 0.01 & \pm 0.03 & \pm 0.04 & \pm 0.04 & \pm 0.03 & \pm 0.08 & \pm 0.08 & \pm 0.02 & \pm 0.01 & \pm 0.04 & \pm 0.05 & \pm 0.09 \\
\hline LEU & $0.63^{f}$ & $1.32^{b}$ & $0.52^{\mathrm{g}}$ & $1.31^{b}$ & $0.63^{f}$ & $1.22^{c}$ & $0.58^{\mathrm{fg}}$ & $1.18^{\mathrm{cd}}$ & $1.13^{d}$ & $0.54 \mathrm{~g}$ & $1.28^{b}$ & $0.62^{f}$ & $1.18^{\mathrm{cd}}$ & $1.16^{\mathrm{cd}}$ & $0.29^{\mathrm{h}}$ & $1.04 \mathrm{e}$ & $1.40^{\mathrm{a}}$ & $1.28^{b}$ \\
\hline$( \pm S E)$ & \pm 0.07 & \pm 0.07 & \pm 0.08 & \pm 0.02 & \pm 0.02 & \pm 0.05 & \pm 0.06 & \pm 0.06 & \pm 0.10 & \pm 0.07 & \pm 0.04 & \pm 0.06 & \pm 0.10 & \pm 0.02 & \pm 0.02 & \pm 0.02 & \pm 0.07 & \pm 0.04 \\
\hline LYS & $0.48^{h}$ & $1.27^{c}$ & $0.38^{i}$ & $1.06^{d}$ & $0.49^{h}$ & $1.21^{\mathrm{c}}$ & $0.53^{\mathrm{h}}$ & $1.14^{\mathrm{cd}}$ & $1.19 \mathrm{c}$ & $0.46^{\mathrm{h}}$ & $1.25^{c}$ & 0.639 & $0.89 \mathrm{e}$ & $0.92^{\mathrm{e}}$ & $0.39 i$ & $0.74^{f}$ & $1.52^{\mathrm{a}}$ & $1.36^{b}$ \\
\hline$( \pm S E)$ & \pm 0.04 & \pm 0.04 & \pm 0.06 & \pm 0.03 & \pm 0.02 & \pm 0.10 & \pm 0.02 & \pm 0.02 & \pm 0.11 & \pm 0.01 & \pm 0.08 & \pm 0.03 & \pm 0.02 & \pm 0.04 & \pm 0.02 & \pm 0.09 & \pm 0.08 & \pm 0.07 \\
\hline HYP & $0.13^{d}$ & $0.06 \mathrm{e}$ & $0.33^{c}$ & $0.33^{c}$ & $0.28^{c}$ & $0.31^{c}$ & $0.29 \mathrm{c}$ & $0.42^{\mathrm{ab}}$ & $0.40^{\mathrm{b}}$ & $0.43^{\mathrm{ab}}$ & $0.39 \mathrm{~b}$ & $0.43^{\mathrm{ab}}$ & $0.47 \mathrm{ab}$ & $0.49 \mathrm{ab}$ & $0.45^{\mathrm{ab}}$ & $0.54^{a}$ & $0.46^{\mathrm{ab}}$ & $0.39^{b}$ \\
\hline$( \pm S E)$ & \pm 0.01 & \pm 0.01 & \pm 0.02 & \pm 0.02 & \pm 0.01 & \pm 0.02 & \pm 0.01 & \pm 0.03 & \pm 0.03 & \pm 0.02 & \pm 0.02 & \pm 0.04 & \pm 0.04 & \pm 0.03 & \pm 0.02 & \pm 0.05 & \pm 0.04 & \pm 0.02 \\
\hline TAA & $7.52^{i}$ & $14.45^{c}$ & $7.66^{i}$ & $13.9^{d}$ & $7.52^{i}$ & $13.61^{\mathrm{de}}$ & $7.70^{i}$ & $15.76^{b}$ & $16.57^{a}$ & $10.03^{g}$ & $16.40^{\mathrm{a}}$ & $9.38^{h}$ & $13.48^{\mathrm{e}}$ & $13.53^{\mathrm{de}}$ & $6.13^{j}$ & $12.15^{\dagger}$ & $16.45^{\mathrm{a}}$ & $13.40^{\mathrm{e}}$ \\
\hline$( \pm S E)$ & \pm 0.33 & \pm 0.04 & \pm 0.27 & \pm 0.17 & \pm 0.09 & \pm 0.37 & \pm 0.49 & \pm 0.32 & \pm 0.48 & \pm 0.22 & \pm 0.12 & \pm 0.84 & \pm 0.78 & \pm 0.45 & \pm 0.12 & \pm 0.51 & \pm 0.24 & \pm 0.23 \\
\hline
\end{tabular}

*Superscripts with different letters in a row are significantly different 0.05 (DO:Design order, TAA:Total Amino acids),

** Optimization procedures suggested by the RSM were performed and obtained data given in $\mathrm{O}_{1}$ and $\mathrm{O}_{2}$ 


\section{CONCLUSION}

In the view of the results, two different hydrolysing procedures were suggested for amino acid analysis in fish meat. Our results were also corrected by the RSM models. According to models, the first procedure was suggested as hydrolysing in $3.79 \mathrm{~N}$ at $110^{\circ} \mathrm{C}$ in 24 hours to get maximum total and essential amino acid contents. The second one was suggested as $3.42 \mathrm{~N}$ at $106.8^{\circ} \mathrm{C}$ in 12.02 hours for maximizing Trp-Asn-GIn which are degraded conventional digestion procedures, often. Besides, despite the acidic hydrolyzation procedure with $\mathrm{HCl}$ is cheap, it can be uneconomic in longstanding processes due to an increasing amount of $\mathrm{HCl}$ and operational costs such as electricity by virtue of constant heating. Leastwise, aforementioned costs were lessened with optimization in the study In conclusion, the mentioned

\section{REFERENCES}

Alvarez, L.V. (2000). Design optimization based on genetic programming. Department of Civil and Environmental Engineering University of Bradford, UK.

Baş, D. \& Boyacı, I. H. (2007). Modeling and optimization I: Usability of response surface methodology. Journal of Food Engineering, 78(3), 836845. DOI: 10.1016/j.jfoodeng.2005.11.024

Bech-Andersen, S. (1991). Determination of tryptophan with HPLC after alkaline hydrolysis in autoclave using a-methyl-tryptophan as İnternal standard. Acta Agriculturae Scandinavica, 41, 305-309. DOI: 10.1080/00015129109439913

Bezerra, M.A., Santelli, R.E., Oliveira, E.P., Villar, L.S. \& Escaleira, L.A. (2008). Response surface methodology (RSM) as a tool for optimization in analytical chemistry. Talanta, 76, 965-977. DOI: 10.1016/j.talanta.2008.05.019

Biesalski, H.K. (2005). Meat as a component of a healthy diet - are there any risks or benefits if meat is avoided in the diet?. Meat Science, 70(3), 509524. DOI: 10.1016/j.meatsci.2004.07.017

Boonyoung, S., Haga, Y. \& Satoh, S. (2012). Preliminary study on effects of methionine hydroxy analog and taurine supplementation in a soy protein concentrate-based diet on the biological performance and amino acid composition of rainbow trout [Oncorhynchus mykiss (Walbaum )] Aquaculture Research, 1-9. DOI: 10.1111/j.1365-2109.2012.03138.x

Çankırılıgil, E. C. \& Berik, N. (2017). Effects of deep-frying to sardine croquettes' chemical composition. Ege Journal of Fisheries and Aquatic Sciences, 34(3), 293-302. DOI: 10.12714/egejfas.2017.34.3.08

Chen, Y.C., Tou, J.C. \& Jaczynski, J. (2007). Amino Acid, fatty acid, and mineral profiles of materials recovered from rainbow trout (Oncorhynchus mykiss) processing by-products using isoelectric solubilization/precipitation. Food Chemistry and Toxicology, 72(9), 528536. DOI: 10.1111/j.1750-3841.2007.00522.x

Cuq, J.-L. \& Firedman, M. (1989). Effect of heat on tryptophan in food: Chemistry, toxicology, and nutritional consequences. In M. Friedman (Ed.), Absorption and utilization of amino acids (Volume 3, pp. 103-128). Boca Raton: Taylor \& Francis. DOI: 10.1201/9781351069441-7

Davarnejad, R., Keshavarz Moraveji, M. \& Havaie, M. (2018). Integral technique for evaluation and optimization of $\mathrm{Ni}$ (II) ions adsorption onto regenerated cellulose using response surface methodology. Arabian Journal of Chemistry, 11(3), 370-379. DOI: 10.1016/j.arabjc.2015.05.022

Dong, Y., Sheng, G., Fu, J. \& Wen, K. (2005). Chemical characterization and anti-anaemia activity of fish protein hydrolysate from Saurida elongata. Journal of the Science of Food and Agriculture, 85(June), 2033-2039. DOI: $10.1002 / j s f a .2219$

Galla, N. R., Karakala, B., Akula, S. \& Pamidighantam, P.R. (2012). Physicochemical, amino acid composition, functional and antioxidant properties hydrolyzation procedures are reliable as well as accurate and they can be used in amino acid analysis by HPLC-DAD as pretreatment in fish meat.

\section{ACKNOWLEDGMENT}

All authors have contributed equally to the article. The data used in this research were obtained from a project which name is "A Research on Possibilities of Using Some Phytobiotic Containing Diets in Black Sea Trout (Salmo trutta labrax PALLAS, 1814) nutrition" supported by General Directorate of Agricultural Research and Policies (TAGEM), Ministry of Agriculture and Forestry, Republic of Turkey. Also authors would like to thank Oytun Ortaylı for technical assistance on Agilent Infinity II HPLC system

of roe protein concentrates obtained from Channa striatus and Lates calcarifer. Food Chemistry, 132(3), 1171-1176. DOI: 10.1016/j.foodchem.2011.11.055

Henderson, J.W., Ricker, R.D., Bidlingmeyer, B.A. \& Woodward, C. (2000). Rapid, accurate, sensitive, and reproducible HPLC analysis of amino acids. U.S.A.

Hosomi, R., Yoshida, M. \& Fukunaga, K. (2012). Seafood consumption and components for health. Global Journal of Health Sciences, 4(3), 72-86. DOI: 10.5539/gjhs.v4n3p72

Hou, Y., Yin, Y. \& Wu, G. (2015). Dietary essentiality of " nutritionally nonessential amino acids "' for animals and humans. Experimental Biology and Medicine, 240, 997-1007. DOI: 10.1177/1535370215587913

Hwang, S.H., Kwon, S.H., Wang, Z., Kim, T.H., Kang, Y.H., Lee, J.Y. \& Lim, S. S. (2016). Optimization of extraction parameters of PTP1 $\beta$ (protein tyrosine phosphatase $1 \beta$ ), inhibitory polyphenols, and anthocyanins from Zea mays L. using response surface methodology (RSM). BMC Complementary and Alternative Medicine, 16(317), 1-10. DOI: 10.1186/s12906-016-1296-5

Joshi, V., Prakash, M.S.A. \& Deepjyoti, S. (2017). Protein and amino acid composition of Indian Himalayan snow trout and their dietary significance. Proceedings of the National Academy of Sciences, India Section B: Biological Sciences, 1-6. DOI: 10.1007/s40011-017-0889-1

Kang, S.I., Kim, K.H., Lee, J.K., Kim, Y.J., Park, S., Kim, M.W., Choi, B.D., Kim, D. \& Kim, J. (2014). Comparison of the food quality of freshwater rainbow trout Oncorhynchus mykiss cultured in different regions. Korean Journal of Fisheries and Aquatic Sciences, 47(April), 103-113. DOI: $10.5657 /$ KFAS.2014.0103

Köksal, G. \& Özel, H.G. (2008). Sağlık Bakanlığı Yayın No: 726, Şubat 2008, Ankara. Erişim tarihi 19 Ağustos 2016. Retrieved from: http://www.saglik.gov.tr/TR/dosya/1-36430/h/a-8- bebek-beslenmesi.pdf) (in Turkish).

Krzynowek, J. \& Murphy, J. (1987). Proximate composition, energy, fatty acid, sodium, and cholesterol content of finfish, shellfish, and their products. NOAA Technical Report NMFS, 55(July), 53. Retrieved from http://spo.nmfs.noaa.gov/tr55opt.pdf

Kurozawa, L.E., Park, K.J. \& Hubiner, M.D. (2008). Optimization of the enzymatic hydrolysis of chicken meat using response surface methodology. Journal of Food Science, 73(5), 405-412. DOI: 10.1111/j.1750-3841.2008.00765.x

Lund, E.K. (2013). Health benefits of seafood; Is it just the fatty acids? Food Chemistry, 140(3), 413-420. DOI: 10.1016/j.foodchem.2013.01.034

Marinho, G.S., Holdt, S. L. \& Angelidaki, I. (2015). Seasonal variations in the amino acid profile and protein nutritional value of Saccharina latissima 
cultivated in a commercial IMTA system. Journal of Applied Phycology, 27(5), 1991-2000. DOI: 10.1007/s10811-015-0546-0

Mohanty, B., Mahanty, A., Ganguly, S., Sankar, T.V., Chakraborty, K., Rangasamy, A., Paul, B., Sarma, D., Mathew, S., Asha, K. K., Behera, B., Debnath, D., Vijayagopal, P., Sridhar, N., Akhtar, M.S., Sahi, N., Mitra, T., Banerjee, S., Paria, P., Das, D., Das, P., Vijayan, K.K., Laxmanan, P. T. \& Sharma, A. P. (2014). Amino acid compositions of 27 food fishes and their importance in clinical nutrition. Journal of Amino Acids, 2014, 1-7. DOI: $10.1155 / 2014 / 269797$

Musarskaya, M., Birch, D. \& Memery, J. (2018). To eat or not to eat: Seafood consumption habit formation. Journal of International Food \& Agribusiness Marketing, 30(3), 227-235. DOI: $10.1080 / 08974438.2017 .1412376$

Nadarajan, R., Azelee, W., Abu, W., Ali, R. \& Ismail, R. (2018). Photocatalytic degradation of 1,2-dichlorobenzene using immobilized $\mathrm{TiO}_{2} / \mathrm{SnO}_{2} / \mathrm{WO}_{3}$ photocatalyst under visible light: Application of response surface methodology. Arabian Journal of Chemistry, 11(1), 34-47. DOI: 10.1016/j.arabjc.2016.03.006

Nielsen, H.K. \& Hurrell, R.F. (1984). Tryptophan determination of food proteins by h.p.l.c. after alkaline hydrolysis. Journal of Science Food and Agriculture, 36, 893-907. DOI: 10.1002/jsfa.2740360920

Nilsang, S., Lertsiri, S., Suphantharika, M. \& Assavanig, A (2005). Optimization of enzymatic hydrolysis of fish soluble concentrate by commercial proteases. Journal of Food Engineering, 70, 571-578. DOI: 10.1016/j.jfoodeng.2004.10.011

Oluwaniyi, O.O., Dosumu, O.O. \& Awolola, G.V. (2010). Effect of local processing methods (boiling, frying and roasting) on the amino acid composition of four marine fishes commonly consumed in Nigeria. Food Chemistry, 123(4), 1000-1006. DOI: 10.1016/j.foodchem.2010.05.051

Özden, Ö. (2005). Changes in amino acid and fatty acid composition during shelf-life of marinated fish. Journal of the Science of Food and Agriculture, 85(12), 2015-2020. DOI: 10.1002/jsfa.2207

Park, E.Y., Brekke, C.J. \& Branen, A.L. (2006). Use of Pacific hake (Merluccius products) in a Frankfurther formulation. Journal of Food Science, 43(6), 1637-1640. DOI: 10.1111/j.1365-2621.1978.tb07376.x

Rebolé, A., Velasco, S., Rodríguez, M.L., Treviño, J., Alzueta, C., Tejedor, J.L., \& Ortiz, L.T. (2015). Nutrient content in the muscle and skin of fillets from farmed rainbow trout (Oncorhynchus mykiss). Food Chemistry, 174, 614620. DOI: 10.1016/j.foodchem.2014.11.072

Said Mohamad, K.A. \& Mohamed Amin, M.A. (2015). Overview on the response surface methodology (RSM) in extraction processes. Journal of Applied Science \& Process Engineering, 2(1), 8-17. DOI: $10.33736 /$ jaspe.161.2015

Sarma, D., Akhtar, M.S., Das, P., Das, P., Shani, N., Ciji, A., Mahanta, P.C., Yengkokpam, S. \& Debnath, D. (2013). Nutritional quality in terms of amino acid and fatty acid of five coldwater fish species: Implications to human health. National Academy Science Letters, 36(4), 385-391. DOI: 10.1007/s40009-013-0151-1

Tahergorabi, R. \& Hosseini, S. V. (2018). Importance of fish consumption in disease prevention. Journal of Birjand University of Medical Sciences, 25(1), 1-9.

Unusan, N. (2007). Change in proximate, amino acid and fatty acid contents in muscle tissue of rainbow trout (Oncorhynchus mykiss) after cooking. International Journal of Food Science and Technology, 42, 1087-1093. DOI: 10.1111/j.1365-2621.2006.01354.X

Varlık, C., Erkan, N., Özden, Ö., Mol, S. \& Baygar, T. (2004). Su ürünleri işleme teknolojisi. İstanbul: İstanbul Üniversitesi Yayın No 4465 Su Ürünleri Fak. № 7.

Vera, L., Zan, M.M. De, Cámara, M.S. \& Goicoechea, C. (2014). Experimental design and multiple response optimization. Using the desirability function in analytical methods development. Talanta, 124, 123-138. DOI: 10.1016/j.talanta.2014.01.034

Widyaningsih, T.D., Widjanarko, S.B., Waziiroh, E., Wijayanti, N. \& Maslukhah, Y.L. (2018). Pilot plant scale extraction of black cincau (Mesona palustris $\mathrm{BL}$ ) using historical-data response surface methodology. International Food Research Journal, 25(2), 712-719.

Wu, G. (2009). Amino acids: metabolism, functions, and nutrition. Amino Acids (2009), 37, 1-17. DOI: 10.1007/s00726-009-0269-0

Wu, G., Wu, Z., Dai, Z., Yang, Y., Wang, W., Liu, C., Wang, B., Wang, J. \& Yin, $Y$. (2013). Dietary requirements of " nutritionally non-essential amino acids "' by animals and humans. Amino Acids (2013), 44, 1107-1113. DOI: $10.1007 / s 00726-012-1444-2$

Zar, j. H. (1999). Biostatistical analysis (4th ed). New Jersey, Prentice-Hall. 